\section{Kortfattet, men omfattende lærebok}

\author{
Jones PB, Buckley PF. \\ Skizofreni \\ Klinisk Praksis. 167 s, tab, ill. København: \\ FADL's Forlag, 2008. Pris DKK 245 \\ ISBN 978-87-7749-284-6
}

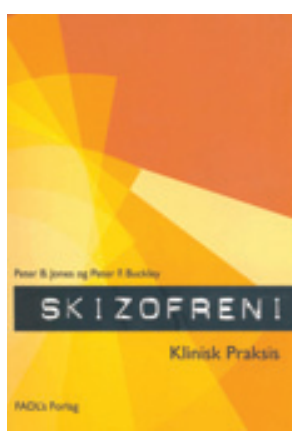

Det heter på omslaget at boken er skrevet for den travle kliniker, men at den kan være nyttig både for sykehuslegen, allmennpraktikeren og sykepleieren. Forfatterne er to erfarne klinikere og forskere, henholdsvis fra England og Irland. Sistnevnte har imidlertid virket i USA siden 1992.

De gir en kort beskrivelse av en rekke aspekter ved schizofreni, så som definisjoner, diagnostikk, årsaksforhold, epidemiologi, forebygging og dessuten behandling i forskjellige faser av sykdommen. Til slutt presenteres fem kasuistikker som blant annet er nyttige beskrivelser av de terapeutiske dilemmaer som kan oppstå for behandlerne, pasientene og deres pårørende. Hovedvekten er lagt på forskningsbasert viten.

I redegjørelsen for den utredning som bør anbefales ved mistanke om en slik alvorlig tilstand, nevnes nevrologisk evaluering, blodprøver og bildediagnostikk, uten at dette konkretiseres tilstrekkelig. Enkelte trykkfeil og utelatelser trekker også ned, f.eks. er paranoid undergruppe uteglemt under presentasjonen av ICD-10-kriteriene. Som vanlig i forbindelse med oversettelse av utenlandsk lærebokstoff vil det gå relativt lang tid fra forfatterne har satt sluttstrek til utgivelsen av den ferdig oversatte bok. Her er over 400 referanser, men de aller fleste er fra 2004 eller tidligere, enkelte fra $2005 \mathrm{og}$ med de to ferskeste artiklene trykt i 2006. På dette feltet skjer det nå så mye, særlig innen biologisk forskning og innen behandlingsforskningen, at noe av stoffet allerede må nyanseres litt.

Dette er imidlertid små innvendinger i forhold til det hovedinntrykket boken gir, nemlig en solid innføring i det viktigste som er verdt å vite om schizofreni for leger, så vel som for andre fagfolk som arbeider med psykotiske pasienter.

\section{Stein Opjordsmoen}

Avdeling for forskning og undervisning

Oslo universitetssykehus

Universitetet i Oslo

\section{Mentalisering på svensk}

Rydén $G$, Wallroth $P$

\section{Mentalisering}

Att leka med verkligheten. $336 \mathrm{~s}$, tab. Stockholm: Natur \& Kultur, 2008. Pris SEK 325 ISBN 978-91-27-02651-3

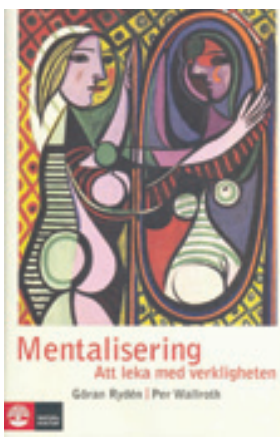

Begrepet mentalisering handler om våre evner til å forstå oss selv og andre, og er en forutsetning for samspill og relasjonsbygging. Psykologiske begreper kommer og går. De beste får oss til å forklare komplekse fenomener på nye vis, se nye sammenhenger, stimulere forskning og påvirke klinisk praksis (1). Mentalisering synes å være et slikt begrep. Mentaliseringstradisjonen er svært ung, men har allerede rukket å få meget stor oppmerksomhet fra fagfolk innen psykologi og psykiatri. Det skyldes dels den enorme produktiviteten til Peter Fonagy, Anthony Bateman og kolleger i London og Jon Allens miljø ved Menninger-klinikken i Texas. Men interessen skyldes også tradisjonens integrerende og inkluderende karakter. Som behandlingstradisjon vektlegges overordnede målsettinger som gjør at terapeuter fra forskjellige tekniske og teoretiske tradisjoner kan føle seg innlemmet samtidig som de blir utfordret til å reflektere over og justere egen praksis (2). Og ikke minst: Det hjelper at det virker. Mentaliseringsbasert terapi (MBT) er kunnskapsbasert praksis for alvorlige kliniske fenomener som borderline personlighetsforstyrrelse.

Psykiateren Göran Rydén og psykologen Per Wallroth har latt seg inspirere av denne tradisjonen, og har stått sentralt i å utvikle et mentaliseringsbasert psykoterapitilbud for pasienter med personlighetsforstyrrelser i Stockholm. Og gjennom denne boken ønsker de å bringe mentaliseringen hjem til Sverige - og Norden. Deres definerte målgruppe er langt flere enn terapeutene; «till alla som är interesserade av psykologi». Og de lykkes med å allmenngjøre mentaliseringstradisjonen gjennom et godt og tilgjengelig språk, og ikke minst gjennom en rekke eksempler fra både klinisk virksomhet og fra hverdagslivets mange utfordringer. Bokens styrke ligger nettopp i det pedagogiske, i å øke tilgjengeligheten til de sentrale elementene i mentaliseringsparadigmet, mer enn i faglig originalitet. Innholdsmessig ligger denne teksten meget tett på originaltekstene av skikkelser som Fonagy, Bateman og Allen.

Mentalisering er et nytt ord for kjente fenomener. Tradisjonens originalitet ligger i å lage synteser mellom psykologi og nevrovitenskapene, mellom kropp og sinn og mellom psykodynamisk psykoterapi og kunnskapsbasert medisin. Mentalisering er kjernen $i$ et nytt intellektuelt rammeverk for psykoterapi. Målet er å skreddersy terapeutiske intervensjoner og holdninger overfor personer med forskjellige patologiske ytringer. Rydén \& Wallroth gir oversiktlige og erfaringsnære introduksjoner til modellens forskjellige elementer - som revidert tilknytningsteori i kjølvannet av Bowlby, mentaliseringsevnenes betydning for affektregulering og psykopatologi, og hjernen. Jeg skulle gjerne ha sett at beskrivelsene av mentaliseringens nevropsykologi hadde vært noe mer utdypende. Og vi blir introdusert til grunnprinsippene i en samtaletradisjon som nettopp forsøker å fremme pasientenes mentaliserende evner.

Boken kan absolutt anbefales; og det gjelder til alle leger. Mentalisering viser til noe som angår oss alle hver eneste dag den enkeltes evner til å se andre innenfra og se seg selv utenfra.

\section{Finn Skårderud}

Avdeling for helse- og sosialfag

Høgskolen i Lillehammer

\section{Litteratur}

1. Karterud S. Mentalisering. Tidsskr Nor Psykologforen 2008; 45: 1374-5.

2. Skårderud F, Sommerfeldt B. Mentalisering et nytt teoretisk og terapeutisk begrep. Tidsskr Nor Legeforen 2008; 128: 1066-9. 